Man and Nature

L'homme et la nature

\title{
The Uses of Shandeanism: The Theatre Criticism of Charles Este
}

\section{Nancy Copeland}

Volume 10, 1991

URI : https://id.erudit.org/iderudit/1012620ar

DOI : https://doi.org/10.7202/1012620ar

Aller au sommaire du numéro

Éditeur(s)

Canadian Society for Eighteenth-Century Studies / Société canadienne d'étude du dix-huitième siècle

ISSN

0824-3298 (imprimé)

1927-8810 (numérique)

Découvrir la revue

Citer cet article

Copeland, N. (1991). The Uses of Shandeanism: The Theatre Criticism of Charles Este. Man and Nature / L'homme et la nature, 10, 31-38.

https://doi.org/10.7202/1012620ar

Copyright (c) Canadian Society for Eighteenth-Century Studies / Sociéte canadienne d'étude du dix-huitième siècle, 1991
Ce document est protégé par la loi sur le droit d'auteur. L'utilisation des services d'Érudit (y compris la reproduction) est assujettie à sa politique d'utilisation que vous pouvez consulter en ligne.

https://apropos.erudit.org/fr/usagers/politique-dutilisation/ 


\section{The Uses of Shandeanism: The Theatre Criticism of Charles Este}

Up until the early 1770s, theatre reviews seldom appeared in English daily newspapers, which were principally devoted to political news and advertising. Matters changed when Henry Bate founded the Morning Post in 1772. The Morning Post differentiated itself from the competition by seeking to entertain its readers, to which end it emphasized the arts, along with sports, science, travel, and gossip (Werkmeister 5-6). Bates's paper was successful and therefore influential, with the result that theatre reviewing became a regular feature of many papers during the 1770 s and 80s, and some, like the Morning Chronicle and the Post itself, became known as 'theatrical papers.' In the early 1780 s the Public Advertiser, which had formerly limited its theatre coverage to 'merely the "accounts" of new plays and frequent unmistakable puffs,' became for a time one of these 'theatrical papers' because of the contributions of the Rev. Charles Este (Gray 253). Este was not only a clergyman, but a theatre enthusiast, who had made an early and abortive attempt at an acting career. Because his contributions were of course anonymous, his tenure at the Public Advertiser cannot be dated precisely, but he was certainly contributing to it by 1782 and had probably stopped by some time in 1786 . His contributions can be identified by their distinctive style, although even this is not decisive: he did not always write in that style, and, as we shall see, it could be, and was, imitated.

This style was the reason for Este's success, and indeed, notoriety. It was described by Este's fellow-journalist John Taylor, who reviewed the theatre for the Morning Post during the 1780s, as apparently being 'founded on that of Sterne in his "Tristram Shandy," consisting of odd breaks, with lines interspersed, and whimsically compounded phrases, strongly studded with quotations, but always connected, forcible, and shrewd, in the opinion of those who thought proper to read his articles with attention' (Taylor 395). While this description is accurate, it is too limited: Taylor exhibits the superficial understanding of Sterne's style, commonplace in the period, which saw it as defined by eccentricity, extravagance, incoherence, and an appearance - if not the fact - of 
senselessness (see Howes, Sterne passim and Yorick 56, 69). Este seems to have had a more profound appreciation of the Shandean style, since his reviews share some of its more fundamental characteristics, among them communication based not on 'determinate ideas' but on shared subjectivity and sympathy; and persuasion based not on logical proofs but on the emotional appeals of rhetoric (Iser 19, Traugott 19, 82).

At this point, it seems useful to introduce some examples. For the purposes of comparison, I have turned to the conventional reviews of the Morning Chronicle and of the Morning Post, when Taylor was chief critic. My first example is drawn from the coverage of Sarah Siddons's benefit on December 23, 1783, at Drury Lane. On this occasion Mrs. Siddons challenged her Covent Garden rival, Ann Crawford, by performing for the first time in one of Mrs. Crawford's most important roles: Lady Randolph in Home's Douglas. The Morning Chronicle report, borrowed from an evening paper, recorded the momentous event in this matter-of-fact manner:

Their difference in the manner of performing ... [the character] was just what we imagined it would be; and was obviously exemplified in two situations which must be familiar to all our dramatic readers.

These 'situations' are the scenes in which Lady Randolph learns from the peasant, Old Norval, that her long-lost son was not drowned at birth as she thought, and the later one in which she reveals to her son that his father was 'Lord' Douglas. The Chronicle continues:

In the tender scene between Old Norval and Lady Randolph, where the first hopes are given that her child is alive and where Mrs. Crawford always seems inspired, Mrs. Siddons does not approach her in any manner that may admit of a comparison. In that wherein she relates to her son the story of his birth, there is just the quantity of passion which is suited to Mrs. Siddons's talents, and too much narration and declamation for the impetuosity of Mrs. Crawford; the former, therefore, greatly excelled the latter in the performance of it.

(24 December 1783)

Here is Este's judgment on the first of these two scenes:

On the whole, to pronounce on this Scene, which is the Sol Altissimus of the Play, and after which the Shadows are very long and abruptly lengthened - on this magnificent Scene - thus prematurely to be praised, - to speak comparatively, - for the Pleasure of John Bull, who it cannot be denied 'is most rascally 
comparative, - the Siddons and the Crawford thus pass comparatively in our Estimation:

The Siddons - younger and more rich in Natural Gifts, - certainly offers much to the Mind, - and yet much more to the Eye.

The Crawford - without these transcendent Advantages of Form and Countenance, and which we lament the Want of, to balance this Period with the preceding one, - the Crawford, however, by some Means or other, offers more to the Heart! - We speak as we feel. - We applauded, though not so loud as Sir C. Thompson, this Scene last night at Drury Lane. - But we did not weep. At Covent Garden we did weep!

(Public Advertiser 24 December 1783)

Prominent among the characteristic features of this passage is the rhetorical creation of subjectivity, using such various devices as the self-reflexive wish that Mrs. Crawford's attributes would allow him to create a symmetrical description of the two actresses; the digression on John Bull; and emotive punctuation and typography. Other notable features include the assertion of feeling as the basis for judgment - 'We speak as we feel'; and the attempt to provide the affective testimony that will persuade the reader of the appropriateness of that judgment - 'At Covent Garden we did weep!'

Este may again be seen attempting to recreate the emotional impact of a performance, this time through a series of adjectives and analogies, in his review of Mrs. Siddons's first London appearance as Lady Macbeth, in February 1785:

Impressing, - contemptuous - tyrannic - remorseless - murderous and repentant - and all so well combined - so well given - so much true sublime and beautiful in every part - that it leaves all the great performances of Mrs. Siddons herself at a distance. It is the Venus of Sir Joshua Reynolds....

(Public Advertiser 8 February 1785)

The unusualness of Este's approach can be judged by comparing it with John Taylor's description of Mrs. Siddons in another role, the lead in Richard Cumberland's 1784 serious drama, The Carmelite. Taylor discusses the role in terms of Mrs. Siddons's previous characterizations, comparing, for example, Matilda's madness in The Carmelite with Belvidera's in Venice Preserved; and then proceeds to a systematic discussion of her delivery of 'sentiments' and 'fine passages,' her 'management of her features,' and her 'declamation' (Morning Post 10 December 1784). 
Este's choice style for his reviews is attributable to the popularity of Sterne and Sterne imitators throughout the 1770s and 80s (Howes, Yorick and Sterne); it may also have owed something to his friendship with the actor John Henderson, who was the leading member of the Shandean Society (Ireland 26-29). But, while Este was only one of many Shandean imitators at the time, he was (it seems) alone in employing the Shandean style in the service of Longinian criticism of anything other than Sterne's own works. To a degree that was perhaps unique, his reviews gave both authority and formal expression to the 'individual sensibility' that was the fundamental principle of the contemporary 'taste' aesthetic (Hooker 586). His unorthodox style comes closer than that of his more conventional competitors to reproducing the 'effect of good Taste' as it is described in John Gilbert Cooper's familiar definition from 1757: 'that instantaneous Glow of Pleasure which thrills thro' our whole Frame, and seizes upon the Applause of the Heart, before the intellectual Power, Reason, can descend from the Throne of the Mind to ratify it's [sic] approbation ...' ('Letter 1: To Euphemius' 2-3). As a result, Este was also better able than other critics to convey the emotional impact that was the principal goal of contemporary performance. In both respects, he anticipates the 'impressionistic' criticism of the early nineteenth century; indeed, Este's declaration, 'We speak as we feel' (Public Advertiser 24 December 1783), prefigures Hazlitt's credo: 'I say what I think: I think what I feel' (in Wellek 2:195).

Este's style was also particularly well-suited to its medium. Este exploits the double-voicedness of the Shandean style to produce a discourse that reflects the 'daily heteroglossia' (Bertelsen 153) which is characteristic of the eighteenth-century newspaper. Lance Bertelsen, describing the Public Advertiser of 1763 in terms which could be applied with equal accuracy to the papers of Este's day, speaks of it as 'a paper structurally embodying the democratic interplay between the commercial language of the advertisements and stocks, the chat and horror of the news, the irreverent wit of certain contributions and the serious moralizing of others' (153-54).

This quality of Este's style is exemplified with particular clarity in a review of Joseph George Holman's Richard the Third, which appeared in the Public Advertiser on January 15, 1785:

The Richard of Holman. 'Aye, every inch a King!' was the praise of Garrick's Richard - as well as his Lear. It is the dispraise - and in a nice age what greater dispraise can well be - that here the reverse is all true? - The strong marks of Mr. Holman's performance are, excessive vulgarity of action and delivery. He is Demosthenes at practice, and the very pebbles in his mouth. In almost every 
action with his arms, his shoulders are raised above his head. For this 'principium et fons' he should observe the ballets d'action of the Opera in public - and call in Simonet in private - The Graces are now expected to attend everything.

Our last words to Mr. Holman - et decies repetita - are THE GRACES! — and in the language of Dr. Ford - 'an easy delivery' -

Here Este combines the discourse of the liberally-educated bourgeois critic, represented by the Latin tags and the references to Demosthenes and correct stage deportment, with more 'genteel' references to polite entertainment - the ballets d'action, and the French dancer Simonet and with the popular discourses of anecdotal theatre history, represented by the reference to a well-known epigram about Garrick's Lear, and sensational journalism, represented by the reference to Dr. Ford, 'a notorious man-midwife' (Gray 259 n.9).

Bertelsen attributes a radical social and political function to eighteenth-century journalistic heteroglossia, linking the 1763 Public Advertiser, edited by Nonsense Club member Bonnell Thornton, to the Club members' other 'articulations of irreverence' (254) that acknowledged 'the power of the common people and the popular idiom in a newly emergent cultural order' (262). Este, according to Taylor, was a 'friend to revolutionary principles' (401) and his Shandean reviews certainly challenged the monologic conventions of critical discourse. The subversive (or at least disruptive) potential of Este's style is suggested by the attacks of his opponents at rival newspapers, who labelled him pejoratively 'the intuitive critick, 'the unintelligible, half-sentence, dash critic,' and 'an illiberal newspaper dealer in puzzling periods, and awkward and unmeaning attempts at wit and poignancy' (in Gray 257 n.8). Even his admirers found his style difficult to understand. Taylor felt obliged to observe that ' $[t]$ here was always point . . . and judgment in his theatrical decisions, which were strikingly manifested, notwithstanding the peculiarity of his style' (395). Similarly James Boaden pointed out that Este 'actually threw out in his rapid hints ... much good remark and refined taste' (2:32).

Yet, as Bertelsen himself recognizes, the question of the relationship during this period between commercialism and radicalism in 'literary production' in general and newspaper writing in particular is a vexed one (Bertelsen 260). Lucyle Werkmeister has described 'Liberty of the Press' as meaning at this time 'a newspaperman's God-given right' to arrange a subsidy from a political party as occasion allowed, 'without coercion of any sort' from partisan shareholders (110). To take Este himself as an example, his own republican sympathies did not interfere 
with his activities as a professional journalist: in the space of a little over one year he arranged that the paper of which he was the conductor, The World, should be subsidized first by the Treasury, then by the 'new Whigs,' and then by the Treasury again (Werkmeister 162, 164, 165-66).

Bertelsen, while acknowledging the profitability that 'rebelliousness and irreverence' could have, nevertheless sees the business of 'literary production' as ultimately productive of real dissent (260-61) and views the very commercialism of the newspapers as an agent of democratization. 'Such a [heteroglot] medium,' he writes, suggested the 'potential reconciliation' of 'clashing idioms ... in the pursuit of goods, services, entertainment, and up-to-date news' (154). Such a 'potential reconciliation' is at least discernable in Este's use of the Shandean style. However, the career of that style at the fashionable daily, The World, demonstrates another possible result of commodification: the support of 'taste' defined in terms of a coterie audience, trivialization, and ephemerality.

The World, or Fashionable Advertiser was founded by Major Edward Topham in January 1787 as a 'newspaper of elegance' and arbiter of 'Taste' (Werkmeister 154). '. . Topham,' Taylor wrote, 'was an enthusiastic admirer of Mr. Este, and uniformly endeavoured to imitate his mode of writing ...' (396). As a result, those parts of the paper which Topham wrote himself - according to Werkmeister, 'most of the miscellany and theatrical commentary' (155) - was written in an imitation of Este's Shandean style. Although Este joined the World as 'conductor' in late 1787, he does not seem to have written theatre criticism for it, with the possible exception of a period in 1789 when Topham felt it necessary to leave London under attacks from his competitors (Werkmeister 160, 191).

As it had been for Este himself (Taylor 395), the oddity of the style was the immediate source of its appeal in The World. The paper, said William Gifford, the editor of the Anti-Jacobin, was 'perfectly unintelligible, and therefore much read....' And Boaden, who edited the rival Oracle, commented that the 'eccentricity of style at first perplexed its readers, at last diverted them ...' (Werkmeister 155). In addition, its suitability for the expression of the 'taste' aesthetic made it an ideal medium for a newspaper that defined itself as 'the sole judge of what was good in the fields of manners and the arts' (Werkmeister 217). Finally, the opportunities it provided for the inclusion of theatrical history, news, and gossip, was far from democratic in its effect when, instead of being used to bring together different types of discourse, it became a miscellany of voguish references addressed to a fashionable readership.

Eventually the World's style played a part in the paper's decline. Taylor wrote: ' . . "The World" had all its columns filled by the same 
strange phraseology, and the public in general looked upon it as a fantastic jargon, that was principally ridiculous, and generally unintelligible. "The World," therefore, gradually declined, and at length was wholly relinquished' (396-97). By 1794 the paper was sold, and was absorbed into the Morning Post (Werkmeister 215, 217), bringing the influence of Este's Shandean style to an end.

Ultimately Shandeanism can be seen to have had mixed consequences for Este's journalism. Inevitably, it deprived him of the authority conferred by monologic critical style, as may be seen from his defenders' eagerness to claim value for his judgments despite 'the peculiarity of his style' (Taylor 395). Indeed, Sterne's work itself was seen 'at best ... a a kind of dazzling chaos in which brilliant fragments jostled each other without plan; at worst [as] . . . a wild farrago of discordant elements' (Howes Sterne 4). In addition, the equivocal ideological potential of this style is indicated by its fate as the house style of The World. On the other hand, however, Shandeanism allowed Este to produce reviews uniquely suited to the theatre of his day and the medium in which they appeared, which offered a challenging alternative to conventional critical discourse, and led his friend and colleague, John Taylor, to memorialize him as 'perhaps the most extraordinary [character] of his time' (394).

NANCY COPELAND

Erindale College, University of Toronto

\section{Works Cited}

Bertelsen, Lance. The Nonsense Club: Literature and Popular Culture, 1749-1764. Oxford: Clarendon, 1986.

Boaden, James. Memoirs of the Life of John Philip Kemble. 2 vols. London, 1825.

Cooper, John Gilbert. Letters Concerning Taste. 3rd ed. 1757. Augustan Reprint Society. 30. Introd. Ralph Cohen. Los Angeles: William Andrews Clark Memorial Library, U of California, 1951.

Gray, Charles H. Theatrical Criticism in London to 1795. 1931. New York: Columbia UP, 1964.

Hooker, Edward Niles. 'The Discussion of Taste, from 1750 to 1770 , and the New Trends in Literary Criticism.' PMLA 49 (1934): 577-92.

Howes, Alan B., ed. Sterne: The Critical Heritage. London: Routledge, 1974.

Yorick and the Critics: Sterne's Reputation in England 1760-1868. Yale Studies in English. Vol. 139. New Haven: Yale UP, 1958. 
Ireland, John. Letters and Poems by the Late John Henderson. London, 1786.

Iser, Wolfgang. Laurence Sterne: Tristram Shandy. Trans. David Henry Wilson. Cambridge: Cambridge UP, 1988.

Taylor, John. Records of My Life. New York, 1833.

Traugott, John. Tristram Shandy's World: Sterne's Philosophical Rhetoric. New York: Russell \& Russell, 1954.

Wellek, Rene. A History of Modern Criticism: 1750-1950. Vol. 2. The Romantics. New Haven: Yale UP, 1955.

Werkmeister, Lucyle. The London Daily Press 1772-1792. Lincoln: University of Nebraska Press, 1963. 